\title{
Genetic Predisposition to Advanced Glycation End Products Toxicity Is Related to Prognosis of Chronic Hemodialysis Patients
}

\author{
Marta Kalousováa Marie Jáchymováa Alexandra Germanováa \\ Aleš Antonín Kuběnac ${ }^{c}$ Vladimír Tesařb Tomáš Zima ${ }^{a}$ \\ anstitute of Clinical Biochemistry and Laboratory Diagnostics, and ${ }^{b}$ Department of Nephrology, \\ First Faculty of Medicine, Charles University in Prague and General University Hospital in Prague, and \\ 'Faculty of Pharmacy Hradec Králové, Charles University in Prague, Prague, Czech Republic
}

\section{Key Words}

Advanced glycation end products $\cdot$ Cardiovascular mortality - Glyoxalase · Hemodialysis • Polymorphisms • Receptor for advanced glycation end products - Soluble receptor for advanced glycation end products

\begin{abstract}
Background: Advanced glycation end products (AGEs) belong to uremic toxins and some pathological effects of AGEs are linked to RAGE (receptor for AGEs). Their precursors are detoxified by the glyoxalase (GLO) system. The A419C (E111A) polymorphism of the GLO I gene is associated with vascular disease in hemodialysis (HD) patients and some RAGE gene polymorphisms are implicated in various pathological states. Aim: To study the relationship of A419C GLO I and four RAGE polymorphisms (-429T/C, $-374 T / A, 2184 \mathrm{~A} / \mathrm{G}$ and Gly82Ser) in the prognosis of HD patients. Methods: The group studied consisted of 214 chronic HD patients prospectively followed up for 43 months. 100 patients died, 48 due to cardiovascular causes. Results: The Kaplan-Meier analysis showed a higher mortality rate in patient-mutated homozygotes for RAGE -429CC, RAGE 2184GG and GLO I 419CC. A higher hazard risk was confirmed by the Cox proportional hazards model when wild-type homozygotes were taken as reference:
\end{abstract}

RAGE -429CC 2.28 (95\% Cl 1.04-4.99), RAGE 2184GG 3.16 (95\% Cl 1.44-6.93), and GLO I 419CC 1.75 (95\% Cl 1.08-2.86). Both RAGE polymorphisms were also associated with cardiovascular mortality: RAGE $-429 \mathrm{CC} 3.54$ (95\% Cl 1.37-9.14) and RAGE 2184GG 5.04 (95\% Cl 1.93-13.11). Conclusion: In summary, our study shows for the first time a link between RAGE and GLO polymorphisms in the prognosis of HD patients.

Copyright $\odot 2010$ S. Karger AG, Basel

\section{Introduction}

Cardiovascular complications are the major cause of death in patients with chronic kidney diseases, especially those on chronic hemodialysis (HD). Apart from classical risk factors, non-traditional mechanisms and uremiaspecific ones have to be taken into consideration when evaluating the risk [1]. Similar to other molecules formed via oxidative and carbonyl stress, advanced glycation end products (AGEs) accumulate in patients with impaired renal function and belong to uremic toxins [2]. Precursors of AGEs, methylglyoxal and glyoxal, are metabolized predominantly by a metalloenzyme glyoxalase I (GLO I). Decreased GLO I activity due to the aging process and oxidative stress results in increased glycation and tissue

\section{KARGER}

Fax +41613061234 E-Mail karger@karger.ch www.karger.com
(C) 2010 S. Karger AG, Base

$1420-4096 / 10 / 0331-0030 \$ 26.00 / 0$

Accessible online at:

www.karger.com/kbr
Assoc. Prof. Marta Kalousová, MD, PhD

Institute of Clinical Chemistry and Laboratory Diagnostics

1st Faculty of Medicine and General University Hospital, Charles University

Karlovo nám. 32, CZ-121 11 Prague 2 (Czech Republic)

Tel. +420 224966 620, Fax +420 224964 2848, E-Mail marta.kalousova @ seznam.cz 
damage [3]. Low-molecular AGEs [4] as well as carboxymethyllysine, one of the AGE products [5], were described as predictors of mortality in patients on chronic HD.

Apart from direct modification of proteins, the pathological effects of some AGEs [6-8] are linked to signaling of specific receptors, from which RAGE (receptor for AGEs) was described first [9]. However, RAGE is a multiligand receptor binding mediator like proinflammatory S100 proteins/calgranulins or amphoterin, both significant in the atherosclerotic milieu [10, 11]. RAGE-ligand interaction is followed by generation of oxidative stress and triggering of inflammatory and proliferative processes which critically contribute to tissue injury [10].

The RAGE gene (AGER - gene encoding RAGE, accession No. M91211) [12] as well as that for GLO I (accession No. L07837) [13] are located on chromosome 6, close to the major histocompatibility complex. Several studies have focused on the genetic background of RAGE and have demonstrated that some gene polymorphisms are implicated in various pathological states, which are of importance also in patients with kidney disease, e.g. amplification of the inflammatory response [14], diabetic complications $[15,16]$, or coronary atherosclerosis $[17$, 18]. Additionally, the A419C (E111A) polymorphisms of the GLO I gene were found to be associated with vascular disease in HD patients [19].

The aim of the present study was to find out whether there is any relationship of A419C GLO I polymorphism and four RAGE polymorphisms (-429T/C, -374T/A, $2184 \mathrm{~A} / \mathrm{G}$ and Gly82Ser) in the prognosis of chronic HD patients.

\section{Subjects and Methods}

\section{Study Design}

214 unrelated Caucasian chronic HD patients from six dialysis centers, in a stable clinical status, were enrolled in the study and prospectively followed up for 43 months from June 2004 to November 2007. Causes of death were recorded and finally classified by two independent physicians as cardiovascular, infection, tumor and others. The study was performed in adherence to the principles of the Declaration of Helsinki and approved by the Institutional Ethical Committee. All patients gave their informed consent prior to entering the study.

\section{Patients' Characteristics}

The HD patients studied consisted of 119 men (56\%) and 95 women (44\%), mean age $63.1 \pm 13.4$ years. Primary renal diagnosis of the patients was as follows: diabetic nephropathy in 40 cases (18.7\%), hypertensive nephropathy in $24(11.2 \%)$, interstitial nephritis in $56(26.2 \%)$, glomerulonephritis in $49(22.9 \%)$, polycystic kidney disease in 25 (11.7\%), and multifactorial in 20 cases
Table 1. Laboratory characteristics of HD patients
Patients, $n$ (male/female)

Age, years

BMI

Leukocytes, $\times 10^{9} / 1$

Hemoglobin, g/l

Hematocrit

Thrombocytes, $\times 10^{9} / 1$

Creatinine, $\mu \mathrm{mol} / \mathrm{l}$

Urea, $\mathrm{mmol} / \mathrm{l}$

Uric acid, $\mu \mathrm{mol} / \mathrm{l}$

Albumin, g/l

Transferrin, g/l

Cholesterol, mmol/l

LDL cholesterol, $\mathrm{mmol} / \mathrm{l}$

HDL cholesterol, mmol/l

Triacylglycerols, $\mathrm{mmol} / \mathrm{l}$

Bilirubin, $\mu \mathrm{mol} / \mathrm{l}$

ALT, $\mu \mathrm{kat} / \mathrm{l}$

CRP, $\mathrm{mg} / \mathrm{l}$

Glucose, $\mathrm{mmol} / \mathrm{l}$

HbA1c, \% $(n=64)$
$214(119 / 95)$

$63.1 \pm 13.4$

$25.4 \pm 4.3$

$6.91 \pm 1.95$

$106 \pm 12.9$

$0.315 \pm 0.039$

$208.0 \pm 75.8$

$757 \pm 204$

$22.7 \pm 6.0$

$382 \pm 89$

$38.1 \pm 3.7$

$1.8 \pm 0.4$

$4.8 \pm 1.1$

$2.6 \pm 0.9$

$1.3 \pm 0.3$

$2.09 \pm 1.24$

$9.6 \pm 3.0$

$0.35 \pm 0.22$

$9.3 \pm 15.3$

$6.2 \pm 2.3$

$5.0 \pm 1.8$
Data are expressed as mean $\pm \mathrm{SD}$. ALT $=$ Alanine aminotransferase; $\mathrm{BMI}=$ body mass index; $\mathrm{CRP}=\mathrm{C}$-reactive protein; $\mathrm{HbAlc}=$ glycated hemoglobin; $\mathrm{HDL}=$ high-density lipoprotein; $\mathrm{LDL}=$ low-density lipoprotein.

(9.3\%). Their mean residual diuresis was $724 \mathrm{ml} / 24 \mathrm{~h}$. The majority of the patients were dialyzed three times a week for $4 \mathrm{~h}$ and their dialysis treatment lasted, on average, for 2.5 years (min. 0.5 years, max. 27 years). They received 5,600 $\pm 2,300$ IU heparin per session, their mean ultrafiltration per session was $667 \mathrm{ml} / \mathrm{h}$, and $\mathrm{Kt} / \mathrm{V} 1.35 \pm 0.22$. HD treatment was performed using conventional bicarbonate-buffered dialysate in all patients. $90 \%$ of the patients used a native arteriovenous fistula for dialysis, in the others an arteriovenous fistula with an artificial graft was used. $89 \%$ of the patients were dialyzed with low-flux dialyzers and in the rest of the group either high-flux dialyzers or both high- and lowflux dialyzers were used. Dialyzer membranes were made of polysulfone $(44 \%)$, diacetate cellulose $(33.5 \%)$, triacetate cellulose (9\%), polymethylmethacrylate $(6 \%)$ and polyamide $(7.5 \%)$. Table 1 depicts the patients' basic laboratory characteristics that were obtained before starting the observation period.

$31 \%$ of patients suffered from diabetes mellitus (half of them were treated with insulin) and $41 \%$ had dyslipidemia (of all patients, $26 \%$ were treated with statins and $4 \%$ with fibrates). The case history of $87 \%$ of patients included hypertension, cardiovascular disease was present in 61\% (acute myocardial infarction in $16 \%$ ), cerebrovascular diseases in $21 \%$ and peripheral vascular disease in $26 \% .10 \%$ of patients were malnourished and $21 \%$ of the patients were smokers. $74 \%$ of patients were currently treated with antihypertensive drugs (angiotensin-converting enzyme inhibitors or angiotensin II receptor-1 blockers in 52\%, $\beta$-blockers in $53 \%$, calcium channel blockers in $30 \%$ and nitrates in $18 \%$ of the 
Table 2. Genotype frequencies of each studied polymorphism in HD patients as assessed in our previous studies $[19,20]$

\begin{tabular}{llll}
\hline Polymorphism & \multicolumn{2}{l}{ Frequencies } & \\
\hline RAGE -429T/C, \% & TT 63.6 & TC 32.7 & CC 3.7 \\
RAGE -374T/A, \% & TT 50.0 & TA 40.7 & AA 9.3 \\
RAGE Gly82Ser (557G/A), \% & GG 93.9 & GS 6.1 & SS 0.0 \\
RAGE 2184A/G, \% & AA 63.4 & AG 33.3 & GG 3.3 \\
GLO I A419C, \% & AA 32.7 & AC 37.4 & CC 29.9 \\
\hline
\end{tabular}

RAGE $2184 \mathrm{~A} / \mathrm{G}$ polymorphism was not determined in $1 \mathrm{pa}-$ tient. GLO I = Glyoxalase I; RAGE = receptor for advanced glycation end products.

total number of patients). Other drugs included diuretics (in $71 \%$ of patients), aspirin or other antiplatelet drugs (67\% of patients), iron, erythropoietin (a weekly average dose of 75 IU/kg b.w.), phosphate binders (predominantly calcium carbonate), and vitamin $\mathrm{D}$, occasionally vitamin $\mathrm{B}$ and $\mathrm{C}$ supplementation.

\section{Laboratory Analyses}

Blood was collected via puncture of the arteriovenous fistula before starting the dialysis session. Tubes containing ethylene diamine tetraacetic acid were used for DNA analysis. Samples for routine biochemical and hematological analyses were also collected.

Four single nucleotide polymorphisms (SNPs) of the RAGE gene -429T/C (rs1800625), -374T/A (rs1800624), Gly82Ser (557G/A, rs2070600) and 2184A/G (rs3134940) and one GLO I polymorphism A419C (rs4746) were determined from DNA extracted from a sample of peripheral blood.

All studied polymorphisms were assessed by PCR-RFLP (polymerase chain reaction-restriction fragment length polymorphism) and for selected samples confirmed by direct sequencing of the PCR product as described previously [19, 20]. Genotype frequencies of both RAGE and GLO I gene polymorphisms have been described in our earlier publications $[19,20]$. For a better overview of further results, see table 2 . Routine laboratory parameters were measured by standard methods.

\section{Statistical Analysis}

Data are expressed as mean \pm SD. Survival analysis was performed with SPSS statistical software (version 16; SPSS, Inc., Chicago, Ill., USA). Both overall mortality and cardiovascular mortality were tested. Kaplan-Meier analysis was used to construct real survival curves. For overall mortality analysis, transplantation and survival till the end of the study were regarded as censored observations. For cardiovascular mortality analysis, additionally, other causes of mortality than cardiovascular were regarded as censoring. Curves were compared with the log-rank test, exceptionally with the Breslow (generalized Wilcoxon) test. Hazard ratios (relative risks of mortality) and appropriate $95 \%$ confidence intervals (CI) were calculated using the Cox proportional hazards model. All results were considered as statistically significant at $\mathrm{p}<0.05$.

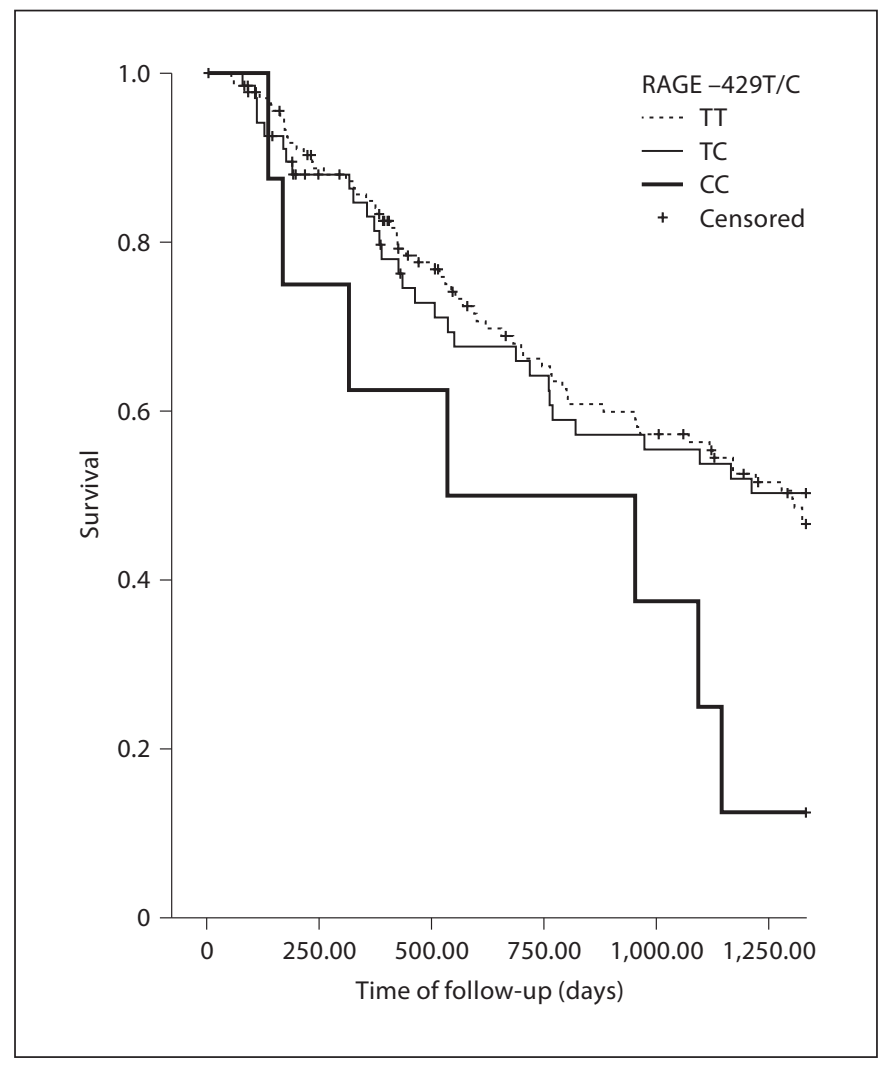

Fig. 1. Kaplan-Meier curves representing overall survival for each genotype of RAGE -429T/C polymorphisms. $\mathrm{p}<0.05$ (log-rank test) CC vs. TT and TC.

\section{Results}

During the 43 months of follow-up, 100 (47\%) patients died. Causes of death were cardiovascular events nearly in a half of the patients (48 patients), infection in 29 , tumor in 10, and other causes in 13 cases. 37 patients were transplanted.

The Kaplan-Meier analysis showed a higher mortality rate in patient-mutated homozygotes for RAGE $-429 \mathrm{~T} / \mathrm{C}$ ( $p<0.05$, log-rank test; fig. 1), RAGE 2184A/G ( $<<0.05$, log-rank test; fig. 2), and GLO I A419C ( $\mathrm{p}=0.055$ : borderline significance in log-rank test, $\mathrm{p}<0.05$, Breslow test; fig. 3). Additionally, similar curves with a significantly worse survival of mutated homozygotes for both mentioned RAGE polymorphisms were obtained when only cardiovascular mortality was considered. A higher hazard risk was also confirmed by the Cox proportional hazards model when wild-type homozygotes were taken as reference (table 3): RAGE -429CC 2.28 (95\% CI 1.04-4.99), RAGE 2184GG 3.16 (95\% CI 1.44-6.93), and GLO I 419CC 


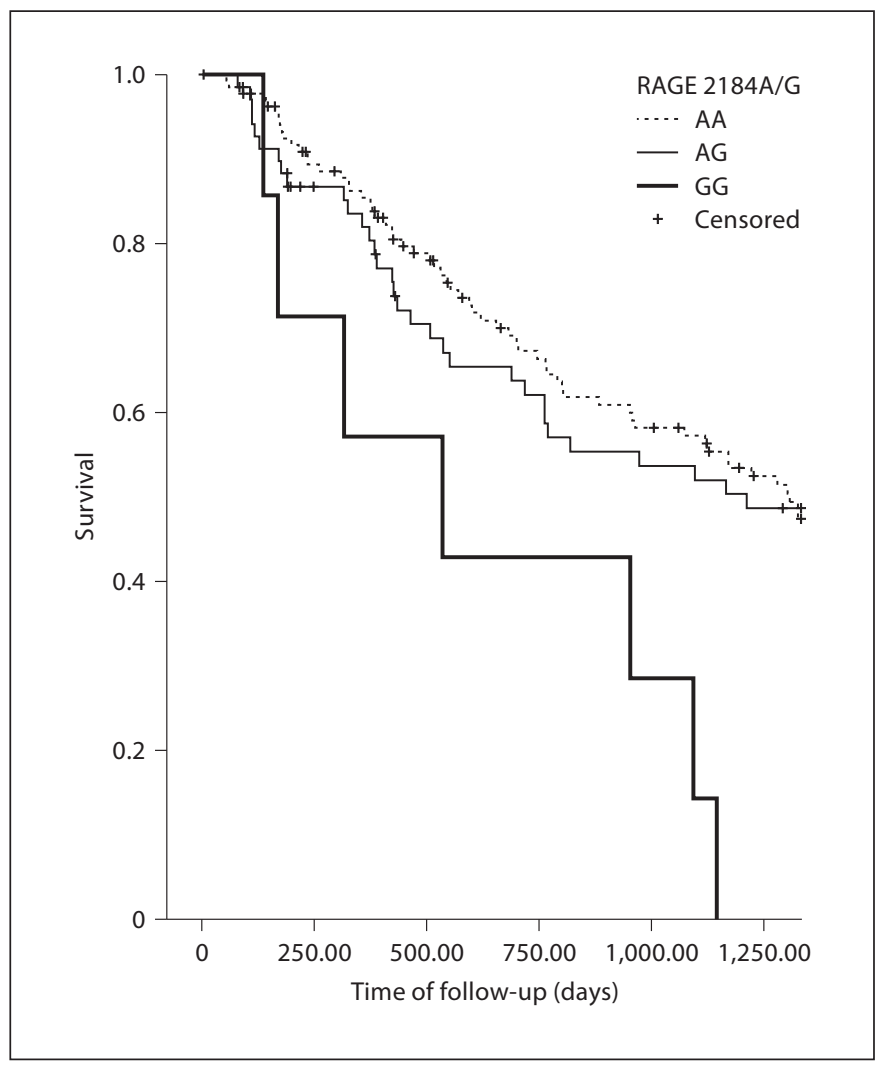

Fig. 2. Kaplan-Meier curves representing overall survival for each genotype of RAGE 2184A/G polymorphisms. $\mathrm{p}<0.05$ (log-rank test) GG vs. AA and AG.

1.75 (95\% CI 1.08-2.86). Both RAGE polymorphisms were also associated with cardiovascular mortality: RAGE -429CC 3.54 (95\% CI 1.37-9.14) and RAGE 2184GG 5.04 (95\% CI 1.93-13.11). In Cox regression, neither overall nor cardiovascular mortality of heterozygotes differed from corresponding wild-type homozygotes. Two further polymorphisms (RAGE -374T/A and RAGE Gly82Ser) studied were not linked either to overall or to cardiovascular mortality of HD patients in our study (table 3 ).

As depicted in table 4, the presence of minor alleles in RAGE -429T/C polymorphism and RAGE 2184A/G polymorphism was tightly linked. We have observed only 7 exceptions, but no patient had both wild-type alleles of one of these polymorphisms and both mutated alleles of the other one. All RAGE -429CC and RAGE 2184GG patients were wild-type homozygous for RAGE -374T/A and RAGE G82S, and for GLO I A419C, 3 patients had AA genotype, 3 had CC genotype and 1 patient had AC genotype.

Genetic Predisposition of AGE Toxicity in HD Patients

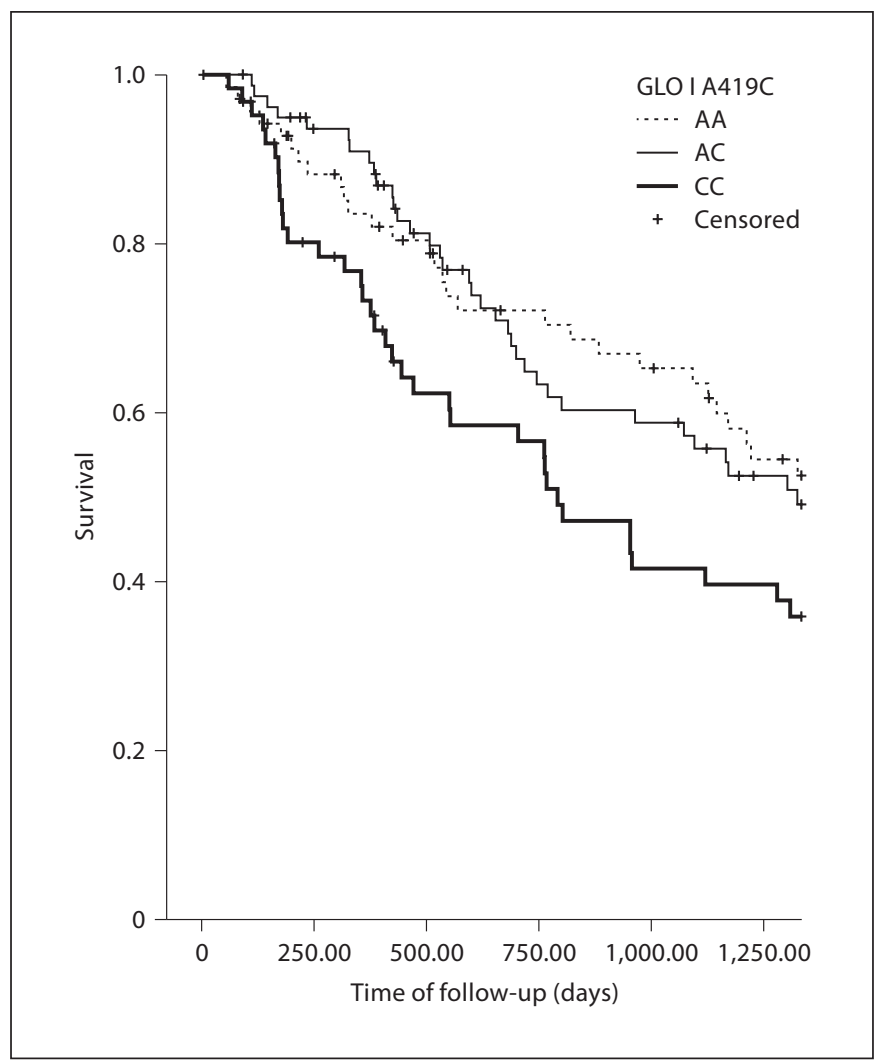

Fig. 3. Kaplan-Meier curves representing overall survival for each genotype of GLO I A419C polymorphisms. $\mathrm{p}=0.055$ (log-rank test), $\mathrm{p}<0.05$ (Breslow - generalized Wilcoxon test) CC vs. AA and $\mathrm{AC}$.

\section{Discussion}

This study shows for the first time a link between some RAGE and GLO polymorphisms in the prognosis of HD patients and thus extends previous knowledge on AGEs and their pathophysiological relevance in these patients to the genetic background. Both RAGE and GLO I polymorphisms have already been studied in other diseases, including cardiovascular or diabetes, which are frequent in HD patients. The significance of RAGE $-429 \mathrm{~T} / \mathrm{C}$ and RAGE $2184 \mathrm{~A} / \mathrm{G}$ polymorphisms was also demonstrated in type 2 diabetics. In these patients, earlier onset of diabetic nephropathy was associated with $-429 \mathrm{C}$ and $2184 \mathrm{G}$ alleles [16]. Additionally, the $2184 \mathrm{~A} / \mathrm{G}$ polymorphism showed a significant association with diabetic nephropathy in type 2 diabetes in single-locus as well as in multilocus analysis [21]. The presence of the $-429 \mathrm{C}$ allele increases transcriptional activities [22] and patients with -429CC genotype also have significantly higher sRAGE

Kidney Blood Press Res 2010;33:30-36 
Table 3. Studied polymorphisms and relative risk of mortality of HD patients

\begin{tabular}{lll}
\hline Polymorphism & Overall mortality, RR $(95 \% \mathrm{CI})$ & Cardiovascular mortality, RR (95\% CI) \\
\hline RAGE -429T/C (CC) & $2.28(1.04-4.99) \mathrm{p}=0.039$ & $3.54(1.37-9.14) \mathrm{p}=0.009$ \\
RAGE -374T/A (AA) & $0.89(0.40-1.97)$ n.s. & $0.56(0.13-2.39) \mathrm{n} . s$. \\
RAGE Gly82Ser (GS) & $0.94(0.41-2.14)$ n.s. & $0.98(0.30-3.15) \mathrm{n} . s$. \\
RAGE 2184A/G (GG) & $3.16(1.44-6.93) \mathrm{p}=0.004$ & $5.04(1.93-13.11) \mathrm{p}=0.001$ \\
GLO I A419C (CC) & $1.75(1.08-2.86) \mathrm{p}=0.024$ & $1.83(0.92-3.73) \mathrm{p}=0.084$, n.s. \\
\hline
\end{tabular}

The risk is calculated for mutated homozygotes, wild-type homozygotes are taken as reference. For RAGE Gly82Ser, the risk is calculated for heterozygotes due to zero frequency of mutated homozygotes in the studied group. Neither overall nor cardiovascular mortality of any heterozygotes differed from corresponding wildtype homozygotes (data not shown).

$\mathrm{CI}=$ Confidence interval; n.s. = not significant; $\mathrm{RR}=$ relative risk of mortality (hazard ratio).

Table 4. Genotype distribution of RAGE -429T/C and RAGE $2184 \mathrm{~A} / \mathrm{G}$ polymorphisms in the studied group of HD patients

\begin{tabular}{lrrrr}
\hline RAGE $2184 \mathrm{~A} / \mathrm{G}$ & \multicolumn{2}{c}{ RAGE $-429 \mathrm{~T} / \mathrm{C}$} & Total \\
\cline { 2 - 4 } & TT & TC & CC & \\
\hline AA & 132 & 3 & 0 & 135 \\
AG & 3 & 67 & 1 & 71 \\
GG & 0 & 0 & 7 & 7 \\
\hline Total & 135 & 70 & 8 & 213 \\
\hline
\end{tabular}

(soluble RAGE) as well as esRAGE (endogenous secretory RAGE) levels [20]. The close connection between these polymorphic $-429 \mathrm{C}$ and $2184 \mathrm{G}$ alleles has to be pointed out and the same is true for the 2184GG genotype, which it is connected with higher sRAGE and esRAGE levels as well [20].

Concerning cardiovascular risk, the A allele of the -374T/A polymorphism, which was also examined in our study, was associated with a decreased risk for cardiovascular disease in the general population or in diabetic patients [15, 17, 18, 23-25]. The Gly82Ser polymorphism was not associated with cardiovascular disease in the Framingham offspring study [26] as well as in patients with rheumatoid arthritis [27]. On the contrary, the minor $82 \mathrm{~A}$ allele containing genotypes were associated with a significantly decreased risk of coronary artery disease [28]. Our study did not demonstrate any association of these polymorphisms with the prognosis of HD patients, suggesting that the results from the general population may not necessarily be valid in every specific patient population. However, it has to be admitted that our findings might also be false negative due to the relatively small sample size.

The A419C polymorphisms of GLO I have also been tested in relationship to other diseases where AGEs are involved in the pathogenesis. In Zuni Indians, the prevalence of GLO I A allele was higher among diabetic participants (type 2 diabetes) than among non-diabetic participants [29]. Another study did not show any association of this SNP with the risk for Alzheimer's disease in the overall population [30]. Our previous study disclosed an association of this polymorphism with vascular disease in HD patients, either cardiovascular or peripheral vascular ones, and to sRAGE levels [19]. This GLO I polymorphism was also of significance in the prognosis of HD patients as shown in Cox regression and less clearly in Kaplan-Meier analysis ( $\mathrm{p}=0.055$ : borderline significance in log-rank test, however significant in Breslow test: $\mathrm{p}<0.05)$. The borderline relationship to cardiovascular mortality $(p=0.084)$ might also be explained by the fact that judgement of the cause of death is very difficult, although two independent physicians were engaged. Another limitation is that genotype frequencies of GLO I polymorphism, unlike all RAGE polymorphisms studied [20], were not in Hardy-Weinberg equilibrium [19]. However, this is in line with findings for other older and younger populations [30], suggesting the existence of some selection forces. Since the GLO I genotypes differed in patients with RAGE 2184GG and RAGE -429CC, we suppose that the presence of these minor genotypes is superior to GLO I genotype.

A combination of RAGE and GLO polymorphisms was chosen as both are involved in AGE metabolism or pathological action. Several years ago, a possible role of GLO in vascular damage was described - a case of a Jap- 
anese woman on chronic HD with multiple cardiovascular complications in absence of predisposing risk factors but with a deficiency of GLO I, and an unusually high level of AGEs (pentosidine and carboxymethyllysine) [31]. Additionally, there is recent evidence that activation of RAGE by S100A12 protein decreases the expression of GLO I and so impairs the enzymatic defense against glycation [32-34]. Previous literature data stimulated us to perform the present study, i.e. to prolong the observation time of our previous study where no association of RAGE polymorphisms with mortality of HD patients was shown [20] and to look at the association of GLO I and prognosis due to its relationship to vascular disease [19]. The abovementioned polymorphisms were chosen for the study as they have shown their relevance in other related diseases. The relatively small number of patients and low occurrence of mutated homozygotes do not exclude false positive or negative findings; however, to our knowledge no such study in HD patients is currently available.
In summary, our study shows for the first time a link between RAGE and GLO polymorphisms in the prognosis of HD patients.

\section{Acknowledgements}

The study was supported by the research project MSM 0021620807 and by project Nucleus by the Elpida Foundation. M. Kalousová is recipient of a L'Oréal CZ for Women in Science 2007 Fellowship. The authors are thankful to the physicians and nurses of the cooperating dialysis centers for technical assistance, especially to Dr. Kratochvilová, Prof. Dusilová-Sulková and Dr. Hodková (Prague), Dr. Gorun (Ústí nad Orlicí), Dr. Hobzek and Mrs. Ždánská (Písek), Dr. Suchanová and Dr. Křížová (Tábor) and Dr. Nýdlová (Strakonice). The authors are equally thankful to the laboratory staff for excellent laboratory skills, especially to Dr. Soukupová, Mrs. Medová, Mrs. Řeháková, and Mrs. Pourová.

\section{References}

1 Locatelli F, Canaud B, Eckardt KU, Stenvinkel P, Wanner C, Zoccali C: Oxidative stress in end-stage renal disease: an emerging threat to patient outcome. Nephrol Dial Transplant 2003;18:1272-1280.

-2 Vanholder R, Baurmeister U, Brunet P, Cohen G, Glorieux G, Jankowski J, European Uremic Toxin Work Group: A bench to bedside view of uremic toxins. J Am Soc Nephrol 2008; 19:863-870.

-3 Thornalley PJ: Glyoxalase I - structure, function and a critical role in the enzymatic defence against glycation. Biochem Soc Trans 2003;31:1343-1348.

4 Roberts MA, Thomas MC, Fernando D, Macmillan N, Power DA, Ierino FL: Low molecular weight advanced glycation end products predict mortality in asymptomatic patients receiving chronic haemodialysis. Nephrol Dial Transplant 2006;21:1611-1617.

-5 Wagner Z, Molnár M, Molnár GA, Tamaskó M, Laczy B, Wagner L, Csiky B, Heidland A, Nagy J, Wittmann I: Serum carboxymethyllysine predicts mortality in hemodialysis patients. Am J Kidney Dis 2006;47:294-300.

-6 Schmidt AM, Hori O, Chen JX, Li JF, Crandall J, Zhang J, Cao R, Yan SD, Brett J, Stern D: Advanced glycation end products interacting with their endothelial receptor induce expression of vascular cell adhesion molecule-1 in cultured human endothelial cells and in mice: a potential mechanism for the accelerated vasculopathy of diabetes. J Clin Invest 1995;96:1395-1403.
7 Kislinger T, Fu C, Huber B, Qu W, Taguchi A, Du Yan S, Hofmann M, Yan SF, Pischetsrieder M, Stern D, Schmidt AM: $\mathrm{N} \varepsilon$ (carboxymethyl)lysine adducts of proteins are ligands for receptor for advanced glycation end products that activate cell signaling pathways and modulate gene expression. J Biol Chem 1999;274:31740-31749.

8 Buetler TM, Leclerc E, Baumeyer A, Latado $\mathrm{H}$, Newell J, Adolfsson O, Parisod V, Richoz J, Maurer S, Foata F, Piguet D, Junod S, Heizmann CW, Delatour T: Ne-carboxymethyllysine-modified proteins are unable to bind to RAGE and activate an inflammatory response. Mol Nutr Food Res 2008;52:370378.

$\checkmark 9$ Neeper M, Schmidt AM, Brett J, Yan SD, Wang F, Pan YC, Elliston K, Stern D, Shaw A: Cloning and expression of a cell surface receptor for advanced glycosylation end products of proteins. J Biol Chem 1992;267: 14998-15004.

10 Schmidt AM, Yan SD, Yan SF, Stern DM: The multiligand receptor RAGE as a progression factor amplifying immune and inflammatory responses. J Clin Invest 2001;108:949955.

11 Basta G: Receptor for advanced glycation end products and atherosclerosis: from basic mechanisms to clinical implications. Atherosclerosis 2008;196:9-21.
12 Sugaya K, Fukagawa T, Matsumoto K, Mita K, Takahashi E, Ando A, Inoko H, Ikemura $\mathrm{T}$ : Three genes in the human MHC class III region near the junction with the class II: gene for receptor of advanced glycosylation end products, PBX2 homeobox gene and a notch homolog, human counterpart of mouse mammary tumor gene int-3. Genomics 1994;23:408-419.

13 Thornalley PJ: The glyoxalase system: new developments towards functional characterization of a metabolic pathway fundamental to biological life. Biochem J 1990;269:1-11.

14 Hofmann MA, Drury S, Hudson BI, Gleason MR, Qu W, Lu Y, Lalla E, Chitnis S, Monteiro J, Stickland MH, Bucciarelli LG, Moser B, Moxley G, Itescu S, Grant PJ, Gregersen PK, Stern DM, Schmidt AM: RAGE and arthritis: the G82S polymorphism amplifies the inflammatory response. Genes Immun 2002; 3:123-135.

15 Pettersson-Fernholm K, Forsblom C, Hudson BI, Perola M, Grant PJ, Groop PH, FinnDiane Study Group: The functional -374 T/A RAGE gene polymorphism is associated with proteinuria and cardiovascular disease in type 1 diabetic patients. Diabetes 2003;52: 891-894.

16 Kanková K, Stejskalová A, Hertlová M, Znojil V: Haplotype analysis of the RAGE gene: identification of a haplotype marker for diabetic nephropathy in type 2 diabetes mellitus. Nephrol Dial Transplant 2005;20:10931102. 
-17 Falcone C, Campo I, Emanuele E, Buzzi MP, Zorzetto M, Sbarsi I, Cuccia M: Relationship between the -374 T/A RAGE gene polymorphism and angiographic coronary artery disease. Int J Mol Med 2004;14:1061-1064.

- 18 Falcone C, Campo I, Emanuele E, Buzzi MP, Geroldi D, Belvito C, Zorzetto M, Sbarsi I, Cuccia M: -374 T/A polymorphism of the RAGE gene promoter in relation to severity of coronary atherosclerosis. Clin Chim Acta 2005;354:111-116.

-19 Kalousová M, Germanová A, Jáchymová M, Mestek O, Tesar V, Zima T: A419C (E111A) polymorphism of the glyoxalase I gene and vascular complications in chronic hemodialysis patients. Ann NY Acad Sci 2008;1126: 268-271.

\20 Kalousová M, Jáchymová M, Mestek O, Hodková M, Kazderová M, Tesar V, Zima T: Receptor for advanced glycation end products - soluble form and gene polymorphisms in chronic haemodialysis patients. Nephrol Dial Transplant 2007;22:2020-2026.

-21 Kanková K, Stejskalová A, Pácal L, Tschoplová S, Hertlová M, Krusová D, IzakovicováHollá L, Beránek M, Vasků A, Barral S, Ott J: Genetic risk factors for diabetic nephropathy on chromosomes $6 \mathrm{p}$ and $7 \mathrm{q}$ identified by the set-association approach. Diabetologia 2007; 50:990-999.

-22 Hudson BI, Stickland MH, Futer TS, Grants PJ: Effect of novel polymorphisms in the RAGE gene on transcriptional regulation and their association with diabetic retinopathy. Diabetes 2001;50:1505-1511.
23 Picheth G, Costantini CO, Pedrosa FO, Leme da Rocha Martinez T, Maltempi de Souza E: The -374A allele of the receptor for advanced glycation end products gene promoter is a protective factor against cardiovascular lesions in type 2 diabetes mellitus patients. Clin Chem Lab Med 2007;45:1268-1272.

24 Dos Santos KG, Canani LH, Gross JL, Tschiedel B, Pires Souto KE, Roisenberg I: The $-374 \mathrm{~A}$ allele of the receptor for advanced glycation end products gene is associated with a decreased risk of ischemic heart disease in African-Brazilians with type 2 diabetes. Mol Genet Metab 2005;85:149-156.

25 Falcone C, Geroldi D, Buzzi MP, Emanuele E, Yilmaz Y, Fontana JM, Vignali L, Boiocchi C, Sbarsi I, Cuccia M: The -374T/A RAGE polymorphism protects against future cardiac events in nondiabetic patients with coronary artery disease. Arch Med Res 2008;39: 320-325.

26 Hofmann MA, Yang Q, Harja E, Kedia P, Gregersen PK, Cupples LA, Schmidt AM, Hudson BI: The RAGE Gly82Ser polymorphism is not associated with cardiovascular disease in the Framingham offspring study. Atherosclerosis 2005;182:301-305.

27 Carroll L, Frazer IH, Turner M, Marwick $\mathrm{MH}$, Thomas R: Receptor for advanced glycation end product glycine 82 serine polymorphism and risk of cardiovascular events in rheumatoid arthritis. Arthritis Res Ther 2007;9:R39.
28 Yoon SJ, Park S, Shim CY, Park CM, Ko YG, Choi D, Park HY, Oh B, Kim H, Jang Y, Chung N: Association of RAGE gene polymorphisms with coronary artery disease in the Korean population. Coron Artery Dis 2007; 18:1-8.

29 Degaffe GH, Vander Jagt DL, Bobelu A, Bobelu J, Neha D, Waikaniwa M, Zager P, Shah VO: Distribution of glyoxalase I polymorphism among Zuni Indians: the Zuni Kidney Project. J Diabetes Complications 2008;22: 267-272.

30 Chen F, Wollmer MA, Hoerndli F, Münch G, Kuhla B, Rogaev EI, Tsolaki M, Papassotiropoulos A, Götz J: Role for glyoxalase I in Alzheimer's disease. Proc Natl Acad Sci USA 2004;101:7687-7692.

-31 Miyata T, van Ypersele de Strihou C, Imasawa T, Yoshino A, Ueda Y, Ogura H, Kominami $\mathrm{K}$, Onogi $\mathrm{H}$, Inagi $\mathrm{R}$, Nangaku $\mathrm{M}$, Kurokawa K: Glyoxalase I deficiency is associated with an unusual level of advanced glycation end products in a hemodialysis patient. Kidney Int 2001;60:2351-2359.

32 Bierhaus A, Nawroth P: Role of AGEs in pain and loss of pain perception. Abstract Book of the 9th International Symposium on the Maillard Reaction, 2007, p 41

33 Thornalley PJ: Dietary AGEs and ALEs and risk to human health by their interaction with the receptor for advanced glycation end products - an introduction. Mol Nutr Food Res 2007;51:1107-1110.

>34 Thornalley PJ, Rabbani N: Highlights and hotspots of protein glycation in end-stage renal disease. Semin Dial 2009;22:400-404 